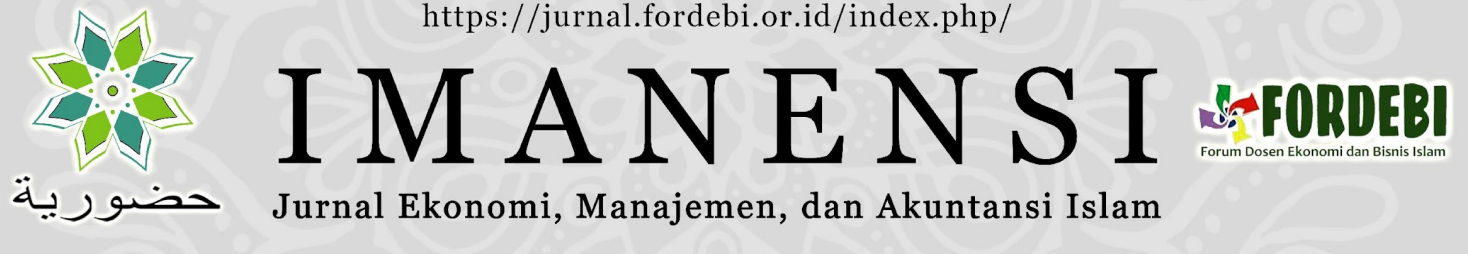

\title{
APAKAH PROFITABILITAS DAN UKURAN PERUSAHAAN BERPERAN MENENTUKAN KEPUTUSAN PEMBAYARAN ZAKAT?
}

\author{
Septiana Kartika Rachmawatia,1, Novrida Qudsi Lutfillah ${ }^{\mathrm{b}, 2^{*}}$, Widi Dwi Ernawatic,3 \\ a,b,c Politeknik Negeri Malang, J1 Soekarno Hatta no.9, Malang, Jawa Timur, 65141, Indonesia \\ ${ }^{1}$ septia.rahma@gmail.com; 2novrida@polinema.ac.id*; ${ }^{3}$ jengwidi@gmail.com \\ ${ }^{*}$ Corresponding author
}

\begin{abstract}
INFO ARTIKEL IMANENSI

Volume 7

Nomor 1

Halaman 23-32

Malang, Maret 2022

ISSN: 2339-1847

e-ISSN: 2683-9968

Kronologi Artikel:

Tanggal Masuk:

22 Januari 2022

Tanggal Revisi:

3 Februari 2022

Tanggal Diterima:

3 Februari 2022

Kata Kunci:

Abstrak: Apakah Profitabilitas dan Ukuran Perusahaan Berperan Menentukan Keputusan Pembayaran Zakat?. Penelitian ini berupaya mengkaji bagaimana profitabilitas dan ukuran perusahaan berperan dalam menentukan keputusan pembayaran zakat Bank Umum Syariah. Regresi linier berganda dipergunakan sebagai metode pada Bank Umum syariah yang terdaftar pada Otoritas Jasa Keuangan (OJK) di Tahun 20122020. Hasil penelitian membuktikan profitabilitas yang diukur dengan $\mathrm{ROE}$ dan ukuran perusahaan berpengaruh terhadap pembayaran zakat Bank Umum Syariah, sedangkan profitabilitas yang diukur dengan ROA dan BOPO tidak memiliki pengaruh bagi Bank Umum Syariah untuk membayar zakat. Sejatinya pembayaran zakat merupakan bentuk kesadaran umat muslim sebagai bentuk ketakwaan kepada Allah SWT, membersihkan diri dan menciptakan semangat cinta dan persatuan diantara umat manusia.
\end{abstract}

Bank Umum Syariah;

BOPO;

Profitabilitas;

Ukuran Perusahaan;

Zakat.

\section{Keywords:}

BOPO;

Company Size;

Profitability;

Sharia Commercial Banks; Zakat.

\begin{abstract}
Do Profitability and Company Size Play a Role in Determining Zakat Payment Decisions?. This study seeks to examine how profitability and company size play a role in determining zakat payment decisions for Islamic Commercial Banks. Multiple linear regression is used as a method for Islamic commercial banks registered with the Financial Services Authority (OJK) in 2012-2020. The results of the study prove that profitability as measured by ROE and company size has an effect on zakat payments for Islamic Commercial Banks, while profitability as measured by ROA and BOPO has no effect on Islamic Commercial Banks paying zakat. In fact, paying zakat is a form of awareness among Muslims as a form of piety to Allah SWT, cleansing themselves and creating a spirit of love and unity among mankind.
\end{abstract}

Disitasi sebagai: Disitasi sebagai: Rachmawati, S.K., Lutfillah, N.Q., \& Ernawati, W.D. (2022). Apakah Profitabilitas dan Ukuran Perusahaan Berperan Menentukan Keputusan Pembayaran Zakat?. IMANENSI: Jurnal Ekonomi Manajemen, dan Akuntansi Islam, 7(1), 23-32. https://doi.org/10.34202/imanensi.7.1.2022.23-32.

\section{PENDAHULUAN}

"Ambilah zakat dari harta mereka, guna membersihkan dan mensucikan mereka, dan berdoalah untuk mereka. Sesungguhnya doa mu itu (menumbuhkan) ketentraman jiwa bagi mereka. Allah Maha mendengar, Maha Mengetahui" (Alquran Surat At-Taubah ayat 103). 
"Wahai sekalian orang-orang yang beriman, nafkahkanlah (keluarkan zakat) sebagian dari hasil usahamu yang baik-baik" (Alquran Surat Al-Baqarah ayat 267).

Pembayaran zakat merupakan salah satu dari lima rukun Islam yang wajib dilaksanakan oleh umat Islam yang memenuhi syarat. Membayar zakat jika merujuk pada surat At Taubah ayat 103 mempunyai konotasi spiritual, yaitu mensucikan dan membersihkan sesuatu dari kotoran atau najis. Dengan demikian, individu yang membayar zakat dikatakan bebas dari kebiasaan buruk seperti keserakahan, keegoisan, dan kesombongan. Secara ekonomi, zakat yang didistribusikan berdampak pada beberapa dimensi ekonomi, seperti konsumsi agregat, tabungan dan investasi, penawaran agregat tenaga kerja dan modal, pengurangan kemiskinan dan pertumbuhan ekonomi (Norazlina \& Rahim, 2011). Praktik pembayaran zakat secara rutin sebesar 10\% dari alokasi keuntungan usaha, dipercaya membawa keberkahan dan kemaslahatan dalam bisnis perdagangan perusahaan (Subakat, 2020; Sari, 2020).

Regulasi pembayaran zakat oleh perusahaan di Indonesia diatur UndangUndang nomor 23 tahun 2011, menyebutkan bagaimana zakat dikelola dan mewajibkan mengeluarkan zakat perusahaan, di mana anggaran dasar telah ditetapkan dengan kewajiban pengeluaran zakat dalam laporan keuangan, juga didasarkan pada ketentuan yang disetujui direksi maupun pemegang saham kepada perusahaan, serta pernyataan kerelaan untuk mengeluarkan zakat (Sudibyo, 2020). Pernyataan perdagangan dan perusahaan adalah objek dan harta yang dikenai zakat menjadi landasan legal bahwa bank syariah adalah salah satu yang wajib mengeluarkan zakat. Akan tetapi, pada penerapannya penyaluran zakat dari perusahaan masih kurang maksimal serta berkelanjutan, terutama di perbankan syariah di Indonesia (Jayanti et al., 2016). Terdapat kaitan erat antara zakat dengan laba yang merupakan hasil dari kinerja finansial suatu perusahaan sebagai alat ukur para stakeholder dalam menilai suatu entitas usaha (Eliana et al., 2020). Laba yang tinggi dapat mengindikasikan penyaluran zakat yang setara, maka perlu diketahui berapa tingkat laba dari suatu entitas usaha yang dapat diukur melalui rasio keuntungan atau profitabilitas dari analisis laporan finansial.

Penerapan perhitungan rasio profitabilitas didasarkan pada mengaitkan antara pos dalam laba rugi dengan neraca yang mengindikasikan kemampuan menghasilkan laba dari perusahaan (Mashuri, 2016). Hasil dari perhitungan yang tinggi mengindikasikan tingkat laba yang tinggi (Firmansyah et al., 2013). Tujuan dari lembaga atau badan usaha pengelola keuangan dalam melakukan usahanya ialah memperoleh laba sehingga rasio profitabilitas pada lembaga dan badan usaha menjadi sangat penting. Tolak ukur keberhasilan kinerja keuangan dalam mengelola aset dapat dilihat melalui rasio-rasio keuangan meliputi rasio return on assets (ROA), rasio return on equity (ROE), serta rasio biaya operasional dan pendapatan operasional (BOPO). Hasil hitung dari rasio bisa dijadikan acuan tingkat keuntungan yang diperoleh, sehingga semakin tinggi hasil tentu makin cepat pula tingkat pengembalian modal melalui laba yang diperoleh (Mashuri, 2016).

Ukuran perusahaan dapat diketahui dari koefisien perusahan dalam menghasilkan keuntungan yang ditinjau dari total asset. Apabila terdapat entitas usaha dengan nilai total asset yang tinggi maka dapat disebut sebagai perusahaan dengan skala besar. Sedangkan apabila perusahaan mempunyai nilai total aset kecil maka perusahaan tergolong memiliki skala kecil. Perusahaan dengan skala besar cenderung mampu membuat kebijakan dalam pengeluaran zakat. berbeda dengan perusahaan dengan skala kecil yang harus mempertimbangkan setiap pengeluaran di dalam perusahaan termasuk dalam pengeluaran zakat. oleh sebab itu, ukuran 
perusahaan mampu mempengaruhi profit perusahaan dalam pengeluaran zakat (Firmansyah et al., 2013) dan (Eliana et al., 2020).

Penelitian sebelumnya menjelaskan jika nilai total aset yang dimiliki perbankan tinggi berarti selaras dengan income sehingga kemungkinan besar bank akan memenuhi kewajiban membayar zakat perusahaan (Sumiayati, 2017); (Firmansyah \& Rusydiana, 2013) dan (Maulana et al., 2019). Ukuran perusahaan yang diukur dengan total bank akan meningkat setiap tahunnya. Pertumbuhan tersebut tidak diimbangi oleh meningkatnya profitabilitas suatu bank, dikarenakan bank umum syariah (BUS) memiliki profitabilitas yang belum stabil bahkan cenderung menurun. Namun jika terdapat nilai laba yang lebih condong menurun, serta nilai skala perusahaan yang lebih condong meningkat, maka dapat dikatakan bahwa BUS dapat meningkatkan pembiayaan dari zakat perusahaan.

Terkait ukuran perusahaan, Eliana, et al (2020) mengungkapkan bahwa ukuran perusahaan tidak memengaruhi profitabilitas perusahaan. Terdapat perusahaan yang mempunyai ukuran perusahaan yang besar ternyata tidak memungkinkan mempunyai keuntungan perusahaan yang tinggi. Hal tersebut dikarenakan perusahaan-perusahaan besar juga harus mengeluarkan banyak biaya dalam kegiatan operasional dibanding dengan perusahaan-perusahaan sejenis namun memiliki ukuran perusahaan yang lebih kecil. Penelitian Firmansyah \& Rusdiana (2013) mendapatkan hasil yang berbeda, ternyata ukuran entitas usaha berpengaruh pada zakat perusahaan yang dibayarkan oleh Bank Umum Syariah. Selaras dengan Widiastuty (2019) ditemukan fakta yaitu perbankan syariah dalam mengeluarkan zakat perusahaan dipengaruhi oleh ukuran entitas usaha. Pada umumnya aset yang dimiliki bank syariah tergolong cukup banyak dan pengelolaannya dilakukan dengan baik sehingga menghasilkan pendapatan yang cukup besar pula sehingga kinerja keuangan bank juga bagus.

Penelitian pengeluaran zakat perusahaan telah banyak diteliti dari penelitian Putrie (2019), Krisdiyanti (2020), Wahyudi (2018), Afandi (2019), Jayanti, et al (2016), Firmansyah, et al (2013), Sumiyati (2017), Widiastuty (2019), Maudi (2020), Rahmayanti (2014), Rhamadhani (2017) dan Maulana (2019). Hasil penelitian tersebut menunjukkan temuan yang berbeda, hal ini menarik minat peneliti agar melakukan penelitian secara mendalam tentang pengeluaran zakat di bank syariah. Rasio profitabilitas diukur tidak hanya dugaan ROA dan ROE, tetapi peneliti menambah BOPO untuk mengukur kinerja keuangan bank (Jayanti et al., 2016). Dengan demikian, adanya efisiensi biaya membuat bank memperoleh keuntungan yang lebih besar, sedangkan jika BOPO semakin tinggi berarti kemampuan bank dalam menekan biaya operasional semakin kurang.

Penelitian ini dimaksudkan untuk mengidentifikasi variabel yang memiliki pengaruh terhadap pengeluaran zakat oleh bank Syariah yaitu profitabilitas dan ukuran perusahaan. Luaran dari penelitian ini pada akhirnya ditujukan sebagai bahan pertimbangan bagi perusahaan-perusahaan maupun lembaga terkait dalam rangka mengelola dan mengeluarkan zakat perusahaan, serta sebagai sarana pendorong perusahaan atau lembaga terkait agar memberikan perhatian sekaligus terlibat aktif dalam praktik pengeluaran zakat perusahaan sebagai penunjang pembangunan perekonomian secara makro dan meningkatkan kondisi ekonomi secara global.

\section{METODE}

Penelitian ini menggunakan populasi bank umum syariah yang telah terdaftar pada Otoritas Jasa Keuangan (OJK) di Tahun 2012-2020, yaitu sejumlah 14 Bank Umum Syariah. Teknik pengambilan sampel menggunakan purposive sampling dan terpilih lima Bank Umum Syariah yang memenuhi kriteria. Periode pengamatan 
sembilan tahun dengan menggunakan analisis data panel, maka jumlah pengamatan sebanyak 45.

Variabel dependen (Y) adalah zakat, syarat yang bisa dirujuk menghitung zakat industri dengan ketentuan perusahaan sudah berhasil berjalan dalam jangka 1 tahun, nisbah zakat perusahaan memiliki besaran yang sama dengan 85 gram emas, persentase nilai zakat sebanyak 2,5\% dan dikenakan dalam perdagangan maupun perusahaan sesuai dengan Badan Nasional Amil Zakat (BASNAS). Adapun variabel independen pada penelitian ini terdiri atas dua bagian, pertama profitabilitas digunakan untuk mengetahui seberapa maksimal upaya dari suatu entitas usaha dalam mendapatkan untung.

Profitability akan diukur dengan menggunakan ROA, ROE, serta BOPO. Untuk dapat menghitung seberapa mampu perbankan menghasilkan profit dengan merata akan digunakan ROA. Hasil dari ROA perbankan, dapat menjadi kesempatan bagi bank untuk memaksimalkan aset yang telah dimiliki untuk menghasilkan laba, sehingga besarnya laba maka menentukan besarnya zakat yang dikeluarkan oleh bank (Rivai et al, 2013: 480). Variabel ukur lainnya yaitu ROE, seringkali digunakan oleh investor serta pemegang saham untuk mengenali serta memperhitungkan kemampuan dari bank untuk mendapatkan net income yang hasil akhirnya juga akan diterima kembali oleh investor. Dengan meningkatnya ROE yang bisa meningkatkan laba atau keuntungan bank, sehingga memengaruhi terhadap zakat yang akan dikeluarkan (Kasmir, 2014: 204). Selanjutnya BOPO yang dapat dipergunakan dalam perhitungan tingkat efisiensi Bank Umum Syariah melaksanakan kegiatan operasionalnya. Dalam hal ini, dapat dilihat apakah BOPO memiliki pengaruh pada zakat yang hendak dikeluarkan atau tidak, diketahui jika biaya operasional dan pendapatan operasional kurang daripada $90 \%$ artinya perusahaan termasuk dalam kriteria baik dalam melaksanakan pengelolaan biaya maupun operasional (Rivai et al, 2013: 480).

Bagian kedua ukuran perusahaan yang menampilkan besar ataupun kecilnya perusahaan sebagai aspek kemampuan perusahaan dalam menciptakan laba. Dalam perhitungan ukuran perusahaan menggunakan proksi logaritma dari aktiva (Sumiyati, 2017). Tujuan dari ini adalah untuk menghindari bias skala. Pengkategorian ukuran perusahaan sesuai dengan menurut Undang-Undang No. 20 Tahun 2008 tentang kriteria ukuran perusahaan besar yang memiliki kekayaan bersih lebih besar dari Rp.10 Miliar termasuk tanah dan bangunan memiliki penjualan lebih dari Rp.50 Miliar/tahun.

Setelah penjabaran variabel dilakukan, maka langkah berikutnya adalah melakukan identifikasi persamaan pengujian. Adapun persamaan yang terbentuk berdasarkan identifikasi variabel adalah:

$$
\begin{aligned}
& Z=a+\beta 1 \mathrm{ROA}+\beta 2 \mathrm{ROE}+\beta 3 \mathrm{BOPO}+\beta 4 \mathrm{UP}+\varepsilon \\
& \text { Keterangan: } \\
& \mathrm{a}=\text { Konstanta } \\
& Z \quad=\text { Zakat } \\
& \mathrm{ROA}=\text { Return on Assets } \\
& \text { ROE = Return on Equity } \\
& \text { BOPO = Biaya Operasional dan Pendapatan Operasional } \\
& \text { UP }=\text { Ukuran Perusahaan } \\
& \varepsilon \quad=\text { Error }
\end{aligned}
$$

Adapun tahapan berikutnya adalah data tersebut ditabulasi dan diolah menggunakan analisis regresi linear berganda. Sebelum uji pengaruh dilakukan, dilakukan uji untuk mengidentifikasi validitas dan reliabilitas data, selanjutnya dilakukan uji untuk memastikan normalitas serta uji lainnya berupa uji asumsi klasik. 
Tabel 1. Statistik Deskriptif

\begin{tabular}{lcccc}
\hline & Minimum & Maksimum & Rerata & $\begin{array}{c}\text { Standar } \\
\text { Deviasi }\end{array}$ \\
\hline ROA & 0,009 & 0,026 & 0,016 & 0,003 \\
ROE & 0,05 & 0,44 & 0,230 & 0,091 \\
BOPO & 0,35 & 1,00 & 0,897 & 0,146 \\
Size & 0,97 & 2,92 & 1,794 & 0,426 \\
ZAKAT & 1,28 & 1,39 & 1,338 & 0,028 \\
\hline
\end{tabular}

\section{HASIL DAN PEMBAHASAN}

Pengujian statistik deskriptif ditujukan untuk seluruh variabel, yaitu profitabilitas dan ukuran perusahaan, sehingga diperoleh gambaran awal data dalam penelitian ini. Tabel 1 menyajikan hasil pengujian statistik deskriptif. Berdasarkan data yang tersaji pada Tabel 1, terlihat bahwa masing-masing variabel memiliki nilai standar deviasi lebih sempit dan mendekati rerata. Hal ini berarti bahwa data memiliki tingkat variasi yang tinggi.

\subsection{Uji Regresi Linear Berganda}

Untuk mengidentifikasi dampak profitabilitas dan ukuran perusahaan terhadap pengeluaran zakat yang dibayarkan Bank Umum Syariah, maka peneliti menggunakan uji regresi. Profitabilitas (ROA, ROE, dan BOPO) dan ukuran perusahaan merupakan variabel independen. Selain itu, pengeluaran zakat merupakan variabel dependen dalam penelitian ini. Hasil uji regresi ini dijelaskan melalui Tabel 2. Adapun berdasarkan data pada Tabel 2, model persamaan yang terbentuk yaitu:

$$
\mathrm{Y}=1,227+1,442 \mathrm{ROA}+0,180 \mathrm{ROE}+0,016 \mathrm{BOPO}+0,018 \mathrm{Size}+\varepsilon \ldots \text { (2) }
$$

Persamaan regresi tersebut bermakna bahwa Nilai konstanta sebesar 1,227 mengindikasikan bahwa apabila variabel independen konstan 0 maka besarnya zakat perusahaan 1,227 (Y) menjelaskan jika independen yang terdiri dari return on asset (ROA), return on equity (ROE), biaya operasional dan pendapatan operasional dan ukuran perusahaan diasumsikan bernilai nol (0) maka besarnya nilai zakat menjadi 1,227. ROA mempunyai nilai koefisien regresi positif sebesar 1,442. maka, nilai koefisien ini menunjukan bahwa ketika ROA mengalami kenaikan sebesar 1 maka zakat akan naik sebesar 1,442, apabila variabel-variabel independen lain nilainya tetap. Koefisien regresi tersebut bernilai positif yang berarti hubungan ROA dan zakat bersifat positif, sehingga kenaikan return on asset perusahan akan linier dengan kenaikan zakat perusahaan tersebut.

ROE mempunyai nilai koefisien regresi positif sebesar 0,189 maka, nilai koefisien menunjukkan bahwa ketika ROE mengalami kenaikan sebesar 1 maka nilai zakat perusahaan akan naik sebesar 0,180, apabila variabel independen lainnya bernilai tetap. Koefisien regresi yang bernilai positif akan menunjukkan hubungan yang berbanding lurus antara ROE dengan zakat. BOPO mempunyai nilai koefisien regresi 0,016. Maka, hal ini menunjukkan bahwa ketika BOPO mengalami kenaikan sebesar 1 maka zakat akan naik menjadi 0,016. Koefisien regresi tersebut bernilai positif yang berarti adanya hubungan antara BOPO dan zakat bersifat positif. Ukuran perusahaan (size) mempunyai nilai regresi positif sebesar 0,018. Jika size mengalami kenaikan sebesar 1 maka nilai zakat perusahaan akan naik sebesar 0,148. koefisien regresi yang bernilai positif ini menunjukkan hubungan yang linear antara size dengan zakat. sehingga kenaikan ukuran perusahaan akan menyebabkan kenaikan pada zakat perusahaan. 


\subsection{Pengaruh Profitabilitas (ROA) terhadap Pengeluaran Zakat Perusahaan}

ROA meraih nilai t hitung 1,811 serta t tabel yaitu sebesar 1,681 yang berarti lebih rendah dengan nilai signifikansi 0,078 dari signifikansi sebesar 0,05. Kondisi yang dihasilkan menjelaskan terkait ROA yang diukur dengan aktiva dibagi dengan laba sebelum pajak mampu mendeteksi aktiva yang dimiliki oleh bank syariah kemungkinan kecil dimaksimalkan dalam penggunaan zakat. Salah satu acuan rentabilitas suatu badan usaha ialah ROA yang memperbandingkan antara income dengan keseluruhan aktiva yang dimiliki. Menurut Jayanti, et al (2016), ROA suatu badan usaha yang telah menjalankan aktivitas operasinya secara efektif akan menghasilkan nilai yang terbaik, sehingga hal ini dapat mengindikasikan kemampuan atas penyaluran zakat oleh perusahaan. Namun, tidak seluruh BUS telah membuat regulasi atas zakat perusahaan serta manajer belum sadar atas pemenuhan nishab hasil usahanya (Sumiyati, 2017)

Penemuan selaras dengan Sumiyati (2017) dan Afandi (2019) dengan penemuan terkait profitabilitas yang ditunjukkan pada ROA tidak memiliki pengaruh atas zakat yang dikeluarkan oleh perusahaan. Profitabilitas di beberapa BUS merumuskan kebijakan penerbitan zakat, dan pengelolaan bank belum sepenuhnya memahami zakat. Dilihat dari keuntungan yang didapat, nilainya sudah mencapai nisab untuk menutupi biaya pengeluaran zakat perusahaan (Sumiyati, 2017). Sedangkan Krisyanti (2020) menyatakan bahwa badan usaha memiliki faktor penentu atas income yang diperoleh yaitu melalui sales, total asset, serta equity. Apabila suatu badan usaha memiliki kemampuan meraih income yang tinggi maka pengelolaan finansialnya akan dianggap baik dan mampu dalam mengeluarkan zakat atas hasil usahanya. Hasil penelitian selaras dengan penelitian Sumiyati (2017) dan menolak hasil Firmansyah, et al (2013) dengan penemuan tidak adanya kaitan atau pengaruh ROA atas zakat yang dikeluarkan oleh BUS.

ROE merupakan perhitungan yang memperbandingkan earning after tax dengan modal. Hasil perhitungan akan memberi gambaran atas seberapa mampu BUS melakukan pengelolaan atas modal yang diinvestasikan untuk menjadikannya keuntungan. Menurut Putrie \& Achiria (2019) dan Jayanti (2014), ditemukan bahwa ROE dapat menjadi acuan kesuksesan suatu badan usaha untuk membagikan dividen kepada investor, sehingga $\mathrm{ROE}$ adalah cerminan dari kekayaan shareholder. Hasil penelitian ini selaras dengan hasil yang dilakukan oleh Afandi (2019) yang menjelaskan bahwa return on equity berdampak pada zakat perusahaan dalam jangka panjang. Hal ini menunjukkan karena bank sebagai lembaga pembiayaan tentunya membutuhkan pendanaan yang terus menerus. Tentu saja, investor dapat memanfaatkan hasil tersebut dengan sebaik-baiknya untuk menghasilkan keuntungan.

\subsection{Pengaruh Profitabilitas (BOPO) terhadap Pengeluaran Zakat Perusahaan}

Hasil regresi pada penelitian ini menunjukkan nilai t hitung sebesar 1,085 di mana lebih kecil dari t tabel 1,681 dengan nilai signifikansi sebesar 0,285 lebih besar dari nilai signifikansi 0,05. Kondisi yang ditemukan menginformasikan bahwa BOPO serta biaya operasi tidak memiliki pengaruh atas zakat yang dibayarkan Bank Umum Syariah. Sedikitnya aktivitas operasi yang dapat menurunkan beban dapat menyebabkan peningkatan laba bersih, bahkan rasio biaya operasional dan pendapatan operasional akan menurun. Maka, melalui perbandingan atas biaya atas operasional serta income, akan dapat terdeteksi efisiensi suatu perbankan yang akan menyebabkan perusahaan atau perbankan mengeluarkan banyak zakat. 
Tabel 2. Ikhtisar Hasil Regresi Linier Berganda dan Pengujian Hipotesis

\begin{tabular}{|c|c|c|c|c|c|}
\hline & \multirow{2}{*}{$\begin{array}{l}\text { Koefisien } \\
\text { Tidak } \\
\text { Terstandar }\end{array}$} & \multicolumn{2}{|c|}{ Koefisien Terstandar } & \multirow[t]{2}{*}{$\mathbf{T}$} & \multirow[t]{2}{*}{ Signifikansi } \\
\hline & & Error & Beta & & \\
\hline Konstanta & 1,227 & 0,016 & & 76,345 & 0,000 \\
\hline $\mathrm{ROA}$ & 1,442 & 0,796 & 0,196 & 1,811 & 0,078 \\
\hline ROE & 0,180 & 0,029 & 0,582 & 6,305 & 0,000 \\
\hline BOPO & 0,016 & 0,015 & 0,082 & 1,085 & 0,285 \\
\hline Ukuran Perusahaan & 0,018 & 0,006 & 0,266 & 2,735 & 0,009 \\
\hline Level of significance (a) & 0,05 & & & & \\
\hline Koefisien Korelasi (r) & 0,882 & & & & \\
\hline Koefisien Determinasi $\left(\mathrm{R}^{2}\right)$ & 0,777 & & & & \\
\hline Adjusted $\mathrm{R}^{2}$ & 0,755 & & & & \\
\hline F-Hitung & 34,936 & & & & \\
\hline Probabilitas (Sig. F) & 0,000 & & & & \\
\hline
\end{tabular}

Rasio BOPO menginformasikan seberapa mampu manajer dari BUS melakukan pengendalian atas biaya yang dikeluarkan untuk aktivitas operasi terhadap penerimaan yang diperoleh. Perhitungannya dengan melakukan perbandingan atas biaya dengan pendapatan operasional. Informasi yang dihimpun adalah beban operasi dan pendapatan operasi setelah pembagian bagi hasil (Muhamad, 2016). Keberhasilan perbankan syariah sangat bergantung pada perolehan income, cara yang paling memungkinkan ialah melalui penghematan pada beban yang dipergunakan memperoleh dana dari masyarakat dan biaya-biaya lain atau biasa disebut dengan istilah biaya operasional dan pendapatan operasional (BOPO). Sebagai shahibul maal atau mudharib, perbankan syariah dituntut untuk berlaku efisien dalam pengelolaan aktivitas agar bisa melakukan penghematan atas biaya yang dapat memperbesar income serta kemaslahatan manajemen dan stockholder umumnya investor yang membutuhkan melalui instrumen zakat (Wahyudi, 2015)

Temuan penelitian mendukung Jayanti (2016), dijelaskan terkait perbankan syariah yang memiliki BOPO dengan hasil perhitungan yang tidak tinggi berarti badan usaha telah melakukan pengelolaan atas beban serta aktivitas operasinya dengan baik. Penelitian ini selaras dengan penelitian Hartini (2016) dimana BOPO tidak memiliki pengaruh atas zakat yang dikeluarkan oleh badan usaha.

\subsection{Pengaruh Ukuran Perusahaan (Size) terhadap Pengeluaran Zakat Perusahaan}

Ukuran perusahaan memiliki nilai t hitung sebesar 2,735 lebih besar dari t tabel sebesar 1,681 dengan nilai signifikansi sebesar 0,009 dan lebih kecil dari nilai signifikansi sebesar 0,05. Kondisi ini menjelaskan terkait ukuran dari badan usaha apabila dilakukan pengukuran melalui logika penjualan yang diraih, maka akan terdeteksi seberapa pengaruhnya terhadap zakat yang dikeluarkan oleh badan usaha tersebut. Sehingga, ditunjukkan adanya pengukuran pada aktiva suatu badan usaha, sumber daya tenaga kerja, dan ukuran atas suatu badan usaha adalah unsur-unsur yang dapat mempengaruhi kelangsungan usaha. Semakin besar ukuran dari suatu badan usaha, kesempatan untuk mendapatkan modal dan keuntungan dan volume usaha semakin besar. Zakat diperoleh dari pengurangan aset dan utang, yaitu persentase $2.5 \%$. Oleh karena itu, keuntungan akan sangat berpengaruh pada pengeluaran atas zakat dari suatu badan usaha. 
Badan usaha dengan kepemilikan atas aktiva yang melimpah akan lebih memaksimalkan pengelolaan sumber daya sebagai penghasil income yang sebanyak mungkin (Rosiana et al., 2016). Bisnis dengan aktiva yang besar mengindikasikan adanya capaian yang tinggi atas pemasukan dan dianggap memiliki masa depan yang baik atau going concern apabila dibandingkan dengan yang hanya memiliki sedikit aktiva (Sumiyati, 2017) dan (Maudi et al., 2020). Maka, perusahaan dengan income serta aktiva besar akan lebih memiliki kebebasan dalam menyalurkan zakat atas hasil usahanya, berbeda dengan perusahaan kecil yang masih akan memiliki banyak pertimbangan (Firmansyah et al., 2013).

Hasil penemuan ini sejalan dengan Rosiana (2016) yang menjelaskan bahwa entitas usaha dengan kepemilikan sumber daya yang melimpah memiliki ukuran yang lebih besar daripada perusahaan kecil. Maka, dapat disimpulkan entitas usaha dengan ukuran yang besar akan lebih leluasa untuk mengeluarkan zakat perusahaan. Sedangkan penelitian ini berbanding terbalik dengan penelitian Romadhani (2020), dalam penemuannya dinyatakan terkait ukuran dari perusahaan tidak memiliki pengaruh atas nilai dari perusahaan.

\subsection{Pengaruh Profitabilitas dan Ukuran Perusahaan terhadap Pengeluaran Zakat Perusahaan}

Hasil pengujian pada Tabel 2 menunjukkan Profitabilitas melalui ROA, ROE, dan BOPO, serta ukuran perusahaan secara bersama-sama memiliki pengaruh atas pengeluaran zakat perusahaan. Hasil tersebut dilihat dari nilai signifikan F sebesar 34,936 dengan tingkat probabilitas (sig.F) sebesar 0,000. Hal ini menunjukkan probabilitas hitung lebih kecil dari level of significance. Nilai Koefisien Determinasi $\left(R^{2}\right)$ sebesar 0,777 dengan Adjusted $R^{2}$ sebesar 0,755. Hal ini memberikan pengertian bahwa 75,5 \% pembayaran zakat dapat dijelaskan oleh ROA, ROE, BOPO, dan ukuran perusahaan, sedangkan sisanya yaitu 24,5\% pembayaran zakat Bank Umum Syariah dipengaruhi oleh variabel-variabel lain yang tidak diteliti dalam penelitian ini. Hal ini menunjukan dengan peningkatan kinerja perusahaan yang ditunjukkan dengan besarnya laba yang diperoleh dan semakin besar ukuran perusahaan maka besar pula pengeluaran zakat yang dikeluarkan perusahaan. Penemuan mendukung Firmansyah, et al (2013); Maulana, et al (2019); Sumiyati (2017) dan Widiastuti (2018).

\section{SIMPULAN}

Berdasarkan hasil dan analisis dapat ditarik kesimpulan secara empiris bahwa profitabilitas yang diukur dengan ROE dan ukuran perusahaan berpengaruh terhadap pembayaran zakat Bank Umum Syariah, sedangkan profitabilitas yang diukur dengan ROA dan BOPO tidak memiliki pengaruh bagi Bank Umum Syariah untuk membayar zakat. Berpengaruh tidaknya profitabilitas dan ukuran perusahaan seharusnya tidak menghalangi kemampuan perusahaan-perusahaan dalam membayar zakat. Pengeluaran zakat bank syariah justru tidak akan mengurangi aset yang dimiliki, apalagi menurunkan kinerja bank syariah. Dengan berzakat maka harta atau aset yang dimiliki akan semakin berkah. Kemampuan Bank Umum Syariah dalam mengeluarkan zakat merupakan bentuk kepedulian dan tanggung jawab sosial suatu perusahaan. Mengoptimalkan suatu kemampuan yang dimiliki oleh perusahaan tidak hanya dibutuhkan kemampuan namun juga diperlukan kemauan dari internal perusahaan. Kemauan perusahaan dapat direalisasikan agar sesuai dengan visi dari perusahaan yaitu melakukan pengeluaran zakat.

Hasil penelitian ini berimplikasi bukan hanya untuk menyadarkan Bank Umum Syariah untuk membayar kewajibannya sebagai umat muslim, tetapi juga untuk Lembaga pendukung penyaluran zakat agar meningkatkan efektivitas 
pembayaran zakat perusahaan untuk meningkatkan pengumpulan zakat nasional. Suatu lembaga penyalur zakat berfungsi mengelola keuangan zakat wajib melakukan pengelolaan finansial secara profesional dalam pengelolaan baik zakat, sedekah, ataupun berupa infaq.

Keterbatasan dalam penelitian ini adalah data hanya terpaku pada Bank Umum Syariah yang berasal dari website dan otoritas jasa keuangan (OJK) serta variabel yang digunakan hanya terbatas pada profitabilitas dan ukuran perusahaan, karena masih ada karakteristik lain seperti kondisi budaya dan sosial yang juga berpengaruh terhadap keputusan untuk membayar zakat. Penelitian lebih lanjut mengenai pembayaran zakat hendaknya tidak hanya fokus pada laba yang didapat Bank Umum Syariah, tetapi juga mencakup masing-masing jenis zakat seperti zakat dari berbagai jenis pendapatan dan zakat dari honorarium profesional juga harus dilakukan.

\section{REFERENSI}

Afandi, M. A (2019). Profitability Variables and Bank Size Effects on Corporate Zakat: Evidence from Indonesian Islamic Banks. International Journal of Zakat. 4(1), 5566.

Eliana, E., Astuti, I. N., Nurbismi, N., \& Riza, A. (2020). Pengaruh Pengeluaran Zakat Perbankan, Ukuran Perusahaan dan Islamic Social Responsibility (ISR) Terhadap Profitabilitas pada Bank Umum Syariah di Indonesia Periode 2016-2019. Jurnal EMT KITA, 4(2), 96. https://doi.org/10.35870/emt.v4i2.145

Firmansyah, I \& Rusydiana, A. S. (2013). Pengaruh Profitabilitas terhadap Pengeluaran Zakat pada Bank Umum Syariah di indonesia dengan Ukuran Perusahaan sebagai Variabel Moderasi. Jurnal Liquidity. 2(2), 110-116.

Hartini, T (2016). Pengaruh Biaya Operasional Dan Pendapatan Operasional (Bopo) Terhadap Profitabilitas Bank Syariah Di Indonesia. I-Finance: A Research Journal on Islamic Finance, 2(1), 20-34.

Jayanti, W. T., Khairani, S., \& Pratiwi, R. (2016). Pengaruh Kinerja Keuangan Terhadap Zakat Bank Umum Syariah Yang Terdaftar Di Bank Indonesia Periode 2010-2014. Jurusan Akuntansi Palembang, 17, 1-10.

Kasmir. (2014). Analisis Laporan Keuangan, Edisi Pertama, Cetakan Ketujuh. PT. Rajagrafindo Persada, Jakarta.

Krisdiyanti, H. R., Rapini, T., \& Farida, U. (2020). Pengaruh Kinerja Keuangan Terhadap Kemampuan Membayar Zakat Perusahaan. ASSET: Jurnal Manajemen dan Bisnis, 2(2), 26-37.https://doi.org/10.24269/asset.v2i2.2387

Mashuri, M. (2016). Analisis Tingkat Profitabilitas Terhadap Pengeluaran Zakat Pada Bank Syariah Mandiri Indonesia. IQTISHADUNA: Jurnal Ilmiah Ekonomi Kita, 5(1), 29-36.

Maudi, A., Amrizal, Pribadi, R. M., \& Cusyana, S. R. (2020). Determinan Profitabilitas dengan Ukuran Perusahaan sebagai Variabel Moderasi pada Bank Umum Syariah. Jurnal Akuntansi Dan Governance, 1(1), 14-23.

Maulana, M. R., Akuntansi, J., \& Ekonomi, F. (2019). Pengaruh Rasio Profitabilitas Terhadap Pengungkapan Zakat Perbankan Syariah Dengan Ukuran Perusahaan Sebagai Variabel Moderasi. Jurnal Akuntansi. 56-74.

Muhamad, (2016), Manajemen Keuangan Syariah; Analisis Fiqih Dan Keuangan. Cetakan kedua, UPP STIM YKPN, Yogyakarta.

Norazlina, A.W. \& Abdul Rahim, A. R. (2011). A framework to analyze the efficiency and governance of zakat institutions. Journal of Islamic Accounting and Business Research, 2(1), 43-62. 
Putrie, R. D. N., \& Achiria, S. (2019). Pengaruh Rasio Profitabilitas Terhadap Zakat Perusahaan Pada Bank Devisa Syariah. Al-Azhar Journal of Islamic Economics, $1(1), 38-48$.

Rahmayanti.D. (2014). Analisis Pengaruh Profitabilitas Terhadap Nilai Perusahaan Dengan Corporate Social Responsibility Sebagai Variabel Pemoderasi Pada Perusahaan. Management Insight. 12(1), 28-40.

Rivai, V., Basir, S., Sudarto., \& Veithzal, P.A. (2013). Manajemen Perbankan Dari Teori ke Praktik. PT Raja Grafindo Persada, Jakarta.

Romadhani, A., Salfi, M., \& Nuzula, N. (2020). Pengaruh profitabilitas, ukuran perusahaan dan kebijakan dividen terhadap nilai perusahaan. Jurnal Administrasi Dan Bisnis, 14(2), 71-81.

Rosiana, R., Arifin, B., \& Hamdani, M. (2016). Pengaruh Ukuran Perusahaan, Profitabilitas, Leverage, Dan Islamic Governance Score Terhadap Pengungkapan Islamic Social Reporting (Studi Empiris pada Bank Umum Syariah di Indonesia Tahun 2010-2012). Esensi, 87-104. https://doi.org/10.15408/ess.v5i1.2334

Sari, G. S. (2020). Zakat Perusahaan Pada Anak Perusahaan Badan Usaha Milik Negara (BUMN) Berbasis Syariah (Studi Kasus Pada PT BRI Syariah Tbk), Jurnal Ilmiah. Universitas Brawijaya.

Subakat, N. (2020). Keberkahan Zakat Perusahaan dalam bisnis di masa Pandemi Covid-19. Seminar Zakat Perusahaan. Jakarta, Baznas TV.

Sudibyo.A, (2020). Seminar Zakat Perusahaan tahun 2020, Badan Amil Zakat Nasional, Jakarta.

Sumiyati, A. (2017). Pengaruh Profitabilitas Terhadap Pengeluaran Zakat dengan Ukuran Perusahaan Sebagai Variabel Moderasi Pada Bank Umum Syariah di Indonesia. Jurnal Pendidikan Akuntansi Dan Keuangan, 5(1), 1-10.

Wahyudi, R. (2015). Pengaruh Zakat terhadap Kinerja Perbankan Syariah di Indonesia. Jurnal Muqaddimah, 21(2), 1-28.

Widiastuty, T. (2019). Peran Ukuran bank, Risiko permodalan, dan tingakt inflasi terhadap pengeluaran zakat bank umum syariah. Prosiding Seminar Nasional Pakar ke 2:1-6. 